\title{
Effect of Fasting on Methionine Adenosyltransferase Expression and the Methionine Cycle in the Mouse Liver
}

\author{
Shigeko Fujimoto SAKATA ${ }^{1}$, Sonomi OKUMURA ${ }^{1}$, Koichi MATSUdA ${ }^{1}$, Yoko HoRIKAWA ${ }^{1}$, \\ Mitsuko MAEDA ${ }^{2}$, Koichi KAWASAKI ${ }^{2}$, Janice Yang CHOU $^{3}$ and Nanaya TAMAKI ${ }^{1}$ \\ ${ }^{1}$ Faculty of Nutrition, and ${ }^{2}$ Faculty of Pharmacy, Kobe Gakuin University, Kobe 651-2180, Japan \\ ${ }^{3}$ National Institutes of Child Health and Human Development
}

(Received October 26, 2004)

\begin{abstract}
Summary The effect of fasting on mouse liver methionine adenosyltransferase (MAT I/ III) expression and the regulation of methionine metabolism were investigated. The mRNA level, protein level, and activity of MAT I/III were increased by fasting for 10 or $16 \mathrm{~h}$. In spite of the increase of MAT I/III activity, $S$-adenosylmethionine, the product of methionine due to MAT I/III, decreased. S-Adenosylhomocysteine, which is made from $S$-adenosylmethionine by its coupling to methyltransferase, increased as a result of fasting for $16 \mathrm{~h}$. These results suggest that the total methylation reactions using $S$-adenosylmethionine are stimulated in the fasting mouse liver. However, the DNA methylation level was not changed by fasting for $16 \mathrm{~h}$. Glutathione, which is made by the transsulfuration pathway from homocysteine, decreased due to fasting. Regulation of supplementation of $S$-adenosylmethionine may occur in the fasting mouse because MAT I/III activity increases and the flow to glutathione is decreased.
\end{abstract}

Key Words methionine adenosyltransferase, adenosylmethionine, fasting, methylation, glutathione

Methionine adenosyltransferase (MAT, EC 2.5.1.6) catalyzes the biosynthesis of $S$-adenosylmethionine (AdoMet) from methionine and ATP. Three forms of MAT (I, II, and III) have been identified in mammalian tissues. Liver-type MAT I and MAT III are the tetramer and dimer, respectively, of identical $\alpha 1$ subunits from the MAT1A gene $(1,2)$. Nonliver-type MAT II is present in the fetal liver, kidney, brain, testis, and lymphocytes $(3,4)$ and is a heteromer of the $\alpha 2$ and $\beta$ subunits from the MAT2A and MAT2B genes, respectively $(1,5,6)$. Hypermethionemic individuals with null MAT1A mutations have developed neurological problems, including brain demyelination (1). In MAT1A knockout mice, the absence of MAT1A in the liver leaves them more susceptible to injury; markers of an acute phase response are expressed, and increased proliferation is evident (7). At 3 mo, knockout mice are more susceptible to cholinedeficient diet-induced fatty liver (7). For MAT II, a switch in gene expression from MAT1A to MAT2A in various human-derived liver cancer cell lines has been reported (8). Mato et al. report that as much as $48 \%$ of methionine metabolism occurs in the liver, and AdoMet is not only an intermediate metabolite in methionine catabolism but also an intracellular control switch that regulates essential hepatic functions such as regeneration, differentiation, and injury (9).

AdoMet contributes to transmethylation $(10,11)$,

E-mail: sakata@nutr.kobegakuin.ac.jp

Abbreviations: MAT, methionine adenosyltransferase; AdoMet, S-adenosylmethionine; AdoHcy, S-adenosylhomocysteine; Hcy, homocysteine; GSH, glutathione. transsulfuration to glutathione (GSH) (12), and, following decarboxylation, is a propylamine group donor in the biosynthesis of polyamines (13) (Fig. 1). AdoMet is an essential methyl donor in transmethylation, and $S$ adenosylhomocysteine (AdoHcy) is known as a potent inhibitor of many methyltransferases, including DNA methyltransferase (14). Increased plasma and lymphocyte AdoHcy levels are associated with increased DNA hypomethylation (15). The ratio of AdoMet to AdoHcy indicates the methylation potential.

Dietary factors such as folate, vitamin $\mathrm{B}_{12}$, and choline change the DNA methylation of genes and lead to chromosomal instability $(15,16)$. Changes of MAT activity due to diet may affect the methylation reaction via the amounts of AdoMet or AdoHcy and may influence the risk of cancer and other diseases. Administration of a high-methionine diet increases MAT III activity in rat liver 4- to 5-fold (17). The activity of hepatic MAT I/III is decreased by vitamin $B_{12}$ deficiency in rats (18). Ethanol feeding or folate deficiency decreases the transcription level of MAT1A in micropigs (19). Fasting for $96 \mathrm{~h}$ in sheep results in a trend toward increasing MAT-specific activity (20). But the role of MAT changes to methionine metabolism, and the mechanism by which MAT is changed by dietary manipulation is not clear. In this study, we investigated the effect of fasting on MAT expression, regulation of the methionine cycle, and DNA methylation in the mouse liver.

\section{MATERIALS AND METHODS}

Reagents. All reagents used were of analytical grade and were purchased from Nacalai Tesque Ltd. (Kyoto, 


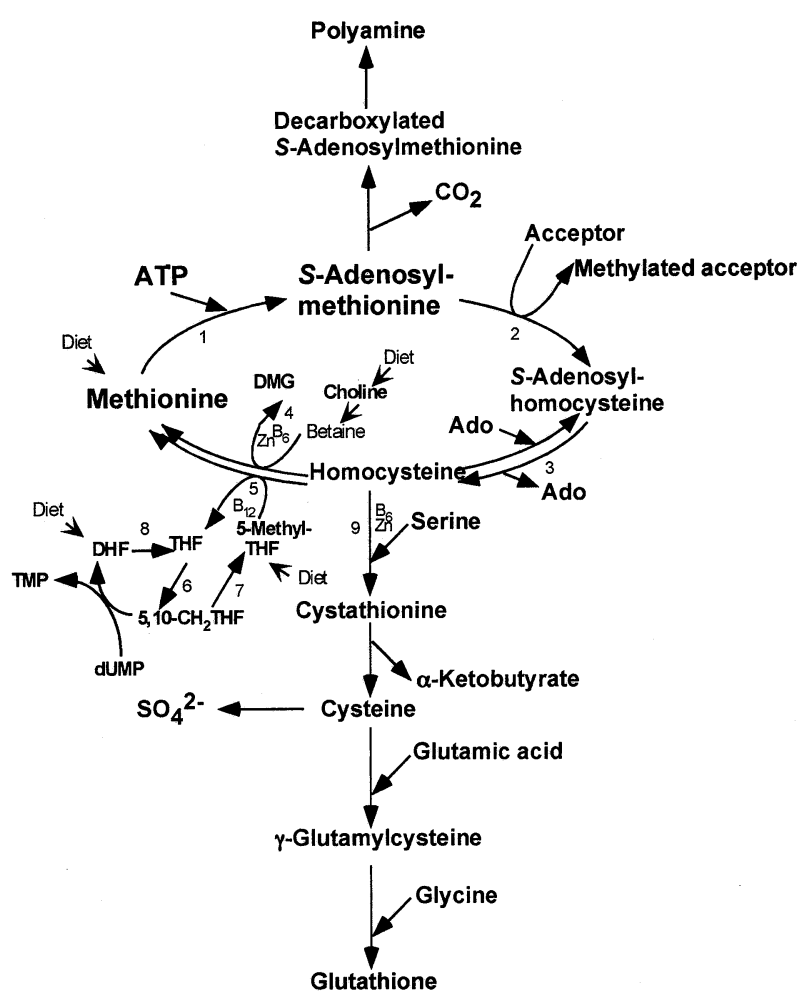

Fig. 1. Methionine metabolic pathway. Enzymes are shown by number in the pathway. 1 , Methionine adenosyltransferase EC 2.5.1.6: MATI/III. 2, Methyltransferase EC 2.1.1-containing glycine $\mathrm{N}$-methyltransferase EC 2.1.1.20: GNMT, liver, kidney, pancreas, phosphatidylethanolamine $N$-methyltransferase EC 2.1.1.17: PEMT2, and DNA (cytosine-5)-methyltransferase EC 2.1.1.37: Dnmt. 3, S-Adenosylhomocysteinase EC 3.3.1.1: SAHH. 4, Betaine-homocysteine S-methyltransferase EC 2.1.1.5: BHMT. 5, 5-Methyltetrahydrofolate-homocysteine $S$-methyltransferase, methionine synthase EC 2.1.1.13: MS. 6, Glycine hydroxymethyltransferase EC 2.1.2.1: GHMT. 7, 5,10-Methylene-tetrahydrofolate reductase $\left(\mathrm{FADH}_{2}\right)$ EC 1.7.99.5: MTHFR. 8, Dihydrofolate reductase EC 1.5.1.3: DHFR. 9, Cystathionine $\beta$-synthase EC 4.2.1.22: CBS.

Japan) unless otherwise stated. Phosphocellulose paper (P81) and DEAEcellulose paper (DE81) were obtained from Whatman International Ltd. CpG methylase was obtained from New England Biolabs. $\left[\alpha^{-}{ }^{32} \mathrm{P}\right] \mathrm{dCTP}, \mathrm{L}-$ [methyl ${ }^{3} \mathrm{H}$ ]methionine, and S-adenosyl-L-[methyl ${ }^{3} \mathrm{H}$ ] methionine were purchased from Amersham Biosciences.

Animal treatments. Male mice ( $d d Y$ strain, 4 wk old, 20-25 g) were purchased from Japan SLC and maintained with laboratory food (MF, Oriental Yeast Co., Ltd., Japan) and water provided ad libitum on a 8:00 to 20:00 light/20:00 to 8:00 dark cycle. In the fasting experiment, diet was withheld from some animals( 3 or 6 mice for the $16 \mathrm{~h}$ fasting experiment or 3 mice for the time course experiment) for 10 or $16 \mathrm{~h}$ starting at 18:00. Tissues were collected from all animals, frozen immediately in liquid nitrogen, and stored at $-80^{\circ} \mathrm{C}$. Food was not withheld from the control animals, and tissues were collected at the same time as those from the fasting group. All procedures were in accordance with the Kobe Gakuin University Guidelines for the Care and Use of Laboratory Animals.

RNA preparation and hybridization analysis. Total RNA was extracted using the acid guanidine thiocyanate-phenol-chloroform method (21). The RNA $(20 \mu \mathrm{g})$ was separated by electrophoresis on a $0.9 \%$ agarose gel containing $2.2 \mathrm{M}$ formaldehyde (22) and transferred to a nylon membrane (Nytran Plus, Schleicher \& Schuell, Germany). The MAT1A/P1 fragment (23), MAT1A/P2 fragment (23), MAT2A fragment (the 1,023 to 1,868 bp fragment of cDNA, AB070266), MAT2B fragment (the 199 to 1,034 bp fragment of cDNA, AB070267), and 18S rRNA fragment were labeled with ${ }^{32} \mathrm{P}$ using a Random Prime DNA Labeling Kit Ver. 2.0 (Takara Shuzo Co., Ltd., Japan) and were used as probes. Hybridization was performed in a solution of PerfectHyb (Toyobo Co., Ltd., Japan). The membranes were washed according to the manufacturer's instructions and then autoradiographed with Fuji RX film at $-70^{\circ} \mathrm{C}$ using intensifying screens. The expression of MAT mRNA was quantified using an imaging analyzer (FLA 2000, Fuji Film Co., Ltd., Japan), and the ratio of the expression of each mRNA-to-18S rRNA signal was calculated and compared.

Measurement of MAT activity and western blot analysis. MAT activity was assayed as described previously (24). Briefly, liver homogenate with $0.25 \mathrm{M}$ Tris $\mathrm{HCl} \mathrm{pH}$ 7.4, $4 \mathrm{~mm}$ 2-mercaptoethanol was centrifuged and the supernatant was added to the assay mixture $(100 \mu \mathrm{L})$ containing $0.1 \mathrm{M}$ Tris $\mathrm{HCl} \mathrm{pH} \mathrm{8.2,20} \mathrm{mM} \mathrm{MgCl}_{2}$, $150 \mathrm{~mm} \mathrm{KCl}, 5 \mathrm{~mm}$ ATP, $5 \mathrm{~mm}$ 2-mercaptoethanol, and $5 \mathrm{mM}$ or $20 \mu \mathrm{M}(185 \mathrm{kBq}) \mathrm{L}-\left[\right.$ methyl $\left.{ }^{3} \mathrm{H}\right]$ methionine. The reaction mixture was incubated for $30 \mathrm{~min}$ at $37^{\circ} \mathrm{C}$, and the reaction was stopped with $10 \mu \mathrm{L}$ of $2 \mathrm{M}$ $\mathrm{HClO}_{4}$ containing $5 \mathrm{mM}$ methionine. After centrifugation, $50 \mu \mathrm{L}$ of the supernatant was spotted onto Whatman P81 phosphocellulose paper, washed in $5 \mathrm{~mm}$ sodium phosphate buffer $\mathrm{pH} 7.0$, and transferred to a counting vial containing $0.4 \mathrm{~mL}$ of $1.5 \mathrm{M} \mathrm{NH}_{4} \mathrm{OH}$. The radioactivity was measured with a liquid scintillation counter. Western blot analysis was performed using the method described previously (25), with anti-mouse MAT I/III rabbit serum.

AdoMet, AdoHcy, GSH, and amino acid measurement. AdoMet and AdoHcy in the liver were measured by the HPLC method (26), using a Waters M-600 pump equipped with a Waters 2487 Dual $\lambda$ Absorbance Detector operating at $254 \mathrm{~nm}$ and a TSK gel ODS-80TM column $(25 \mathrm{~cm} \times 4.6 \mathrm{~mm}$, Tosoh Co., Kyoto, Japan $)$. GSH was measured by the microtiter plate assay (27). For the amino acid measurements, liver homogenate with $0.4 \mathrm{M} \mathrm{HClO}_{4}$ was centrifuged, and the supernatant was neutralized with $4 \mathrm{M} \mathrm{KOH}$. After centrifugation, the supernatant was concentrated with a Speed Vacuum Concentrator (Savant, USA) and resuspended to $1 / 10$ vol. $0.1 \mathrm{M} \mathrm{HCl}$. After that, the amino acids were measured with the PTC-amino acid method by HPLC with a Pico-Tag column ( $15 \mathrm{~cm} \times 3.9 \mathrm{~mm}$, Waters $)(28)$.

DNA methylation. Genomic DNA was prepared from 
A
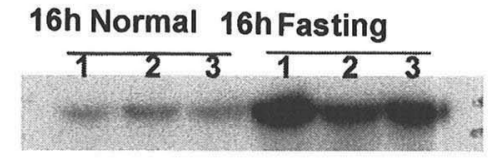

MAT1AVP1

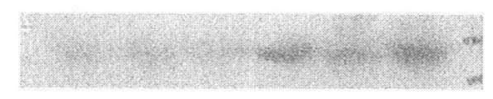

MATIA/P2

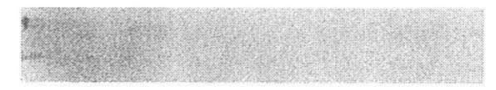

MAT2A

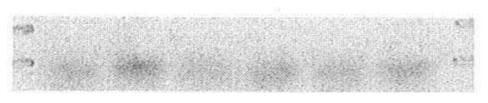

MAT2B
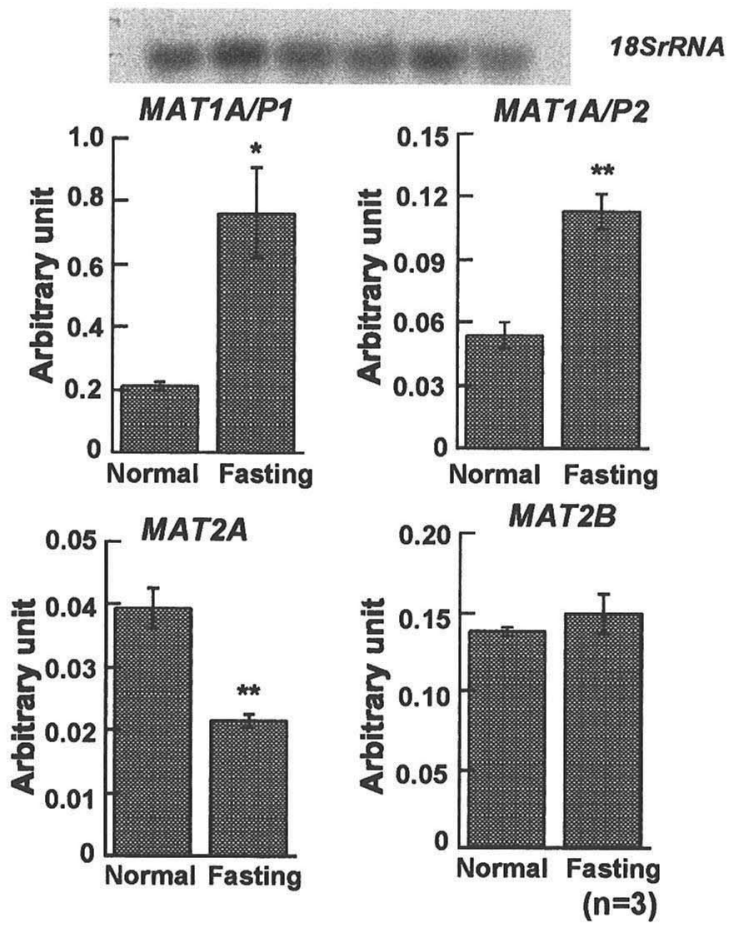

mouse liver according to a previously described method (29). The reaction mixture $(30 \mu \mathrm{L})$ containing $0.5 \mu \mathrm{g}$ DNA, $3 \mu \mathrm{M}$ S-adenosyl-L-[methyl ${ }^{3} \mathrm{H}$ ]methionine (74 $\mathrm{kBq}$ ), 3 units of $\mathrm{CpG}$ methylase, $10 \mathrm{~mm}$ Tris $\mathrm{HCl}$ at $\mathrm{pH}$ 7.9, $120 \mathrm{~mm} \mathrm{NaCl}, 10 \mathrm{~mm}$ EDTA, and $1 \mathrm{~mm}$ dithiothreitol was incubated at $30^{\circ} \mathrm{C}$ for $1 \mathrm{~h}$. The methylated DNA was isolated from the reaction mixture by filtering $15 \mu \mathrm{L}$ on Whatman DE81 ion exchange paper. After washing, the radioactivity remaining on the paper was measured in a liquid scintillation counter (30).

Other methods and statistical analysis. Protein concentration was measured by the dye-binding method using a protein assay (Bio-Rad, Japan). Bovine serum albumin was used as the standard. Groups in all experiments were compared using the non-paired Student's $t$ test.

\section{RESULTS}

MAT expression in the fasting mouse liver

MAT 1A mRNA increased in the fasting mouse liver. The MAT1A gene has two promoters in the $5^{\prime}$ region (23). The pl promoter gives rise to the P1 transcript ini-

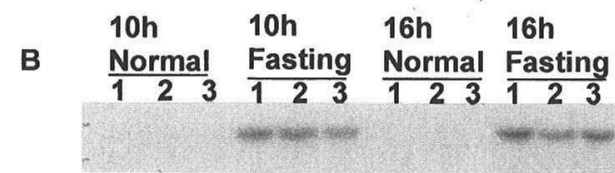

MAT1A/P1

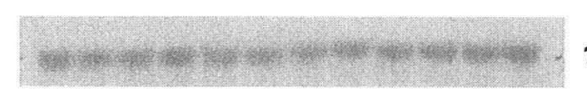

18SrRNA

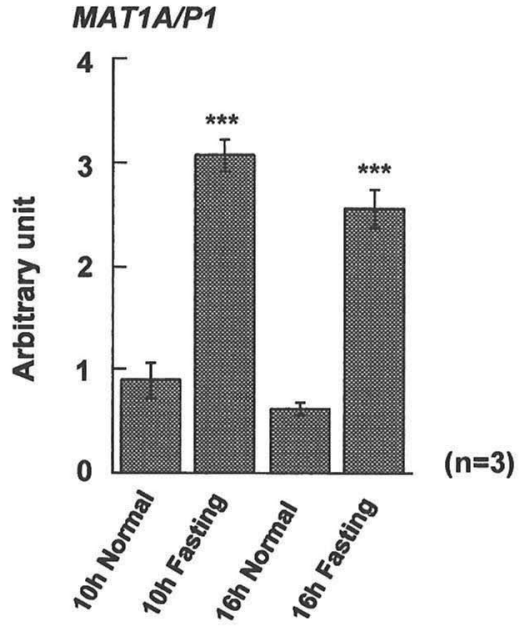

Fig. 2. Effect of fasting on MAT mRNA expression in the mouse liver. (A) Effect of $16 \mathrm{~h}$ of fasting on MAT mRNA expression for MAT I/III and MAT II. (B) Effect of fasting time on MAT mRNA expression for MAT I/III. Northern hybridizations were performed with the specific probe for each MAT transcript. The mean \pm SE of the ratio of each MAT mRNA to the level of the $18 \mathrm{~S}$ rRNA signal is shown as an arbitrary unit. * $p<0.05$. ** $p<0.01$, and **** $p<0.001$ : significantly different from each normal group.

tiated at +1 , and the $\mathrm{p} 2$ promoter gives rise to the $\mathrm{P} 2$ transcript initiated at -156 . Both the $\mathrm{P} 1$ and $\mathrm{P} 2$ transcripts have the same translation initiation site. However, because the -107 to +145 nucleotide region is missing from the mature $\mathrm{P} 2$ transcript, the $\mathrm{P} 1$ and $\mathrm{P} 2$ transcripts are detected separately by the transcript-specific probes (MAT1A/P1 and MAT1A/P2). As shown in Fig. 2A, both MAT1A/P1 and P2 mRNA increased after $16 \mathrm{~h}$ of fasting. MAT2A mRNA decreased, and MAT2B mRNA did not change expression level. Figure 2B shows the effect of fasting time on the expression of MAT1A/P1 mRNA, which is the major transcript in the liver. MAT1A/P1 mRNA started to increase at $10 \mathrm{~h}$. The protein level of MAT I/III from the MAT1A gene increased after $16 \mathrm{~h}$ but not after $10 \mathrm{~h}$ of fasting (Fig. 3). The MAT activity, measured with $5 \mathrm{~mm}$ substrate, increased after $16 \mathrm{~h}$ of fasting. The enzyme activity with $5 \mathrm{~mm}$ substrate indicates activity of MAT I/III because the $\mathrm{Km}$ value of MAT I/III for methionine is $23 \mu \mathrm{M}$ to $1 \mathrm{~mm}$ for MAT I and $215 \mu \mathrm{M}$ to $7 \mathrm{~mm}$ for MAT III. The activity with $20 \mu \mathrm{M}$ substrate shows MAT II activity (the $\mathrm{Km}$ value for methionine is 4 to $10 \mu \mathrm{M}$ for MAT II). 

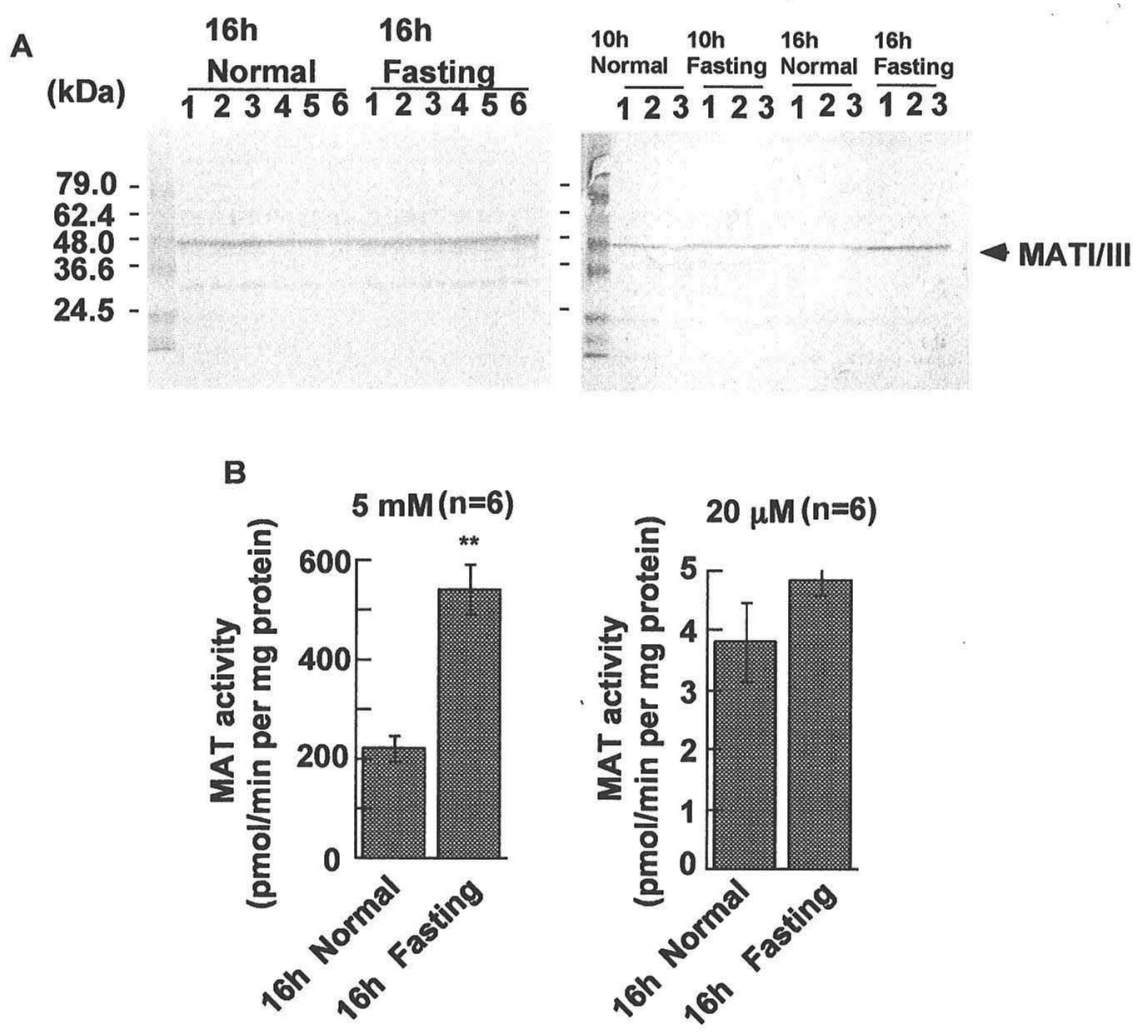

Fig. 3. Effect of fasting on MAT protein level and activity. (A) Western blot analysis. (B) MAT activity. Each data point is shown as mean \pm SE. ** $p<0.01$ : significantly different from the normal group.

Table 1. Methylation potential and GSH level in $16 \mathrm{~h}$-fasting-mouse liver.

\begin{tabular}{|c|c|c|c|c|c|}
\hline \multirow{2}{*}{ Groups } & AdoMet & AdoHcy & \multirow{2}{*}{$\begin{array}{l}\text { AdoMet/AdoHcy } \\
\text { ratio }\end{array}$} & \multirow{2}{*}{$\begin{array}{c}\text { Total GSH } \\
\text { ( } \mu \mathrm{mol} / \mathrm{g} \text { liver })\end{array}$} & \multirow{2}{*}{$\begin{array}{c}\text { Incorporation } \\
\text { of methyl group } \\
(\mathrm{dpm} / 0.25 \mu \mathrm{g} \text { DNA) }\end{array}$} \\
\hline & \multicolumn{2}{|c|}{ (nmol/g liver) } & & & \\
\hline Normal & $83.9 \pm 4.0$ & $6.3 \pm 1.5$ & $19.6 \pm 5.8$ & $4.24 \pm 0.17$ & $9.278 \pm 697$ \\
\hline Fasting & $63.2 \pm 3.2^{* * *}$ & $15.2 \pm 2.4^{*}$ & $5.1 \pm 1.3^{*}$ & $2.90 \pm 0.11^{* * *}$ & $13,682 \pm 2,137$ \\
\hline
\end{tabular}

Each datum is mean \pm SE $(n=6)$.

${ }^{*} p<0.05,{ }^{* *} p<0.01$ : significantly different from normal group.

Table 2. Amino acid levels in $16 \mathrm{~h}$-fasting-mouse liver.

\begin{tabular}{ccc}
\hline Amino acid & $\begin{array}{c}\text { Normal } \\
\text { (nmol/g liver) }\end{array}$ & $\begin{array}{c}\text { Fasting } \\
\text { (nmol/g liver) }\end{array}$ \\
\hline Asp & $412 \pm 61$ & $482 \pm 61$ \\
Glu & $1,946 \pm 381$ & $1,603 \pm 266$ \\
Ser & $319 \pm 42$ & $342 \pm 29$ \\
Gly & $3,146 \pm 225$ & $2,823 \pm 278$ \\
Thr & $156 \pm 34$ & $178 \pm 31$ \\
Ala & $1,710 \pm 382$ & $477 \pm 77^{*}$ \\
Met & $107 \pm 14$ & $119 \pm 25$ \\
Leu & $151 \pm 73$ & $182 \pm 42$ \\
Lys & $376 \pm 69$ & $348 \pm 24$ \\
\hline
\end{tabular}

Each datum is mean \pm SE $(n=6)$.

${ }^{*} p<0.05$ : significantly different from normal group.
The activity with $20 \mu \mathrm{M}$ methionine did not change after $16 \mathrm{~h}$ of fasting.

Effect of fasting on hepatic metabolites and DNA methylation

After $16 \mathrm{~h}$ of fasting, AdoMet decreased and AdoHcy increased significantly (Table 1). The AdoMet/AdoHcy ratio, which shows the methylation potential, decreased to one fourth. However, in vitro incorporation of the methyl group into DNA by $\mathrm{CpG}$ methylase did not change, showing that the DNA methylation level did not change in the fasting mouse liver. The level of GSH, which is synthesized by the $\gamma$-glutamyl cycle as a byproduct of the transsulfuration pathway, was decreased by fasting (Table 1). Alanine is known to decrease due to fasting (31). As shown in Table 2, alanine decreased after $16 \mathrm{~h}$ of fasting, but the methionine level in the liver did not change. Free homocysteine (Hcy) was not detected in the livers of either control or fasting mice. 


\section{DISCUSSION}

In this study, we investigated the effect of fasting on MAT expression and the regulation of the methionine cycle in mice. MAT1A mRNA level and activity increased in mouse liver after $16 \mathrm{~h}$ of fasting. The AdoMet/AdoHcy ratio decreased as a result of fasting, but the DNA methylation level did not change.

The enzymes in the methionine metabolic pathway may be regulated to maintain the levels of methionine and AdoMet in the fasting mouse liver; MAT I/III activity increased and the methionine level remained constant in fasting mouse liver (Fig. 3 and Table 2). Mudd and Poole have estimated that about $53 \%$ of the available homocysteine is converted to cystathionine during each cycle in males fed a basal diet (32). GSH, which is the most abundant low-molecular-weight thiol, is made by the transsulfuration pathway. In 3-mo-old MAT1A knockout mice, the plasma methionine level increases $776 \%$, and hepatic AdoMet and GSH are reduced by 74 and $40 \%$, respectively (7). This result and our results for GSH in the fasting mouse liver (Table 1) indicate that when AdoMet is low, the transsulfuration pathway may down-regulate to maintain the level of AdoMet. GSH deficiency contributes to oxidative stress, which plays a key role in aging and the pathogenesis of many diseases (33). Thus, long-term fasting may contribute to oxidative stress.

AdoMet, which is made by MAT in the methionine cycle, is essentially a methyl donor for DNA methylation. DNA methylation is the covalent addition of a methyl group to the 5-carbon position of cytosine. In normal situations, 60 to $90 \%$ of all CpG sequences in the genome are methylated. Unmethylated $\mathrm{CpG}$ sequences are mainly clustered in CpG-rich sequences, termed $\mathrm{CpG}$ islands, within the promoter regions of genes (34). Methylation of $\mathrm{CpG}$ islands inhibits gene transcription by directly inhibiting the binding of transcription factors to their cis-acting sites on DNA (35). As a consequence of folate deficiency, cellular AdoMet is depleted, which in turn induces DNA hypomethylation and potentially induces proto-oncogene expression, leading to cancer. In addition, DNA hypomethylation has been shown to lead to chromosomal instability in embryonic stem cells that are null for the DNA methyltransferase 1 gene (36). Many reports indicate that dietary modifications change DNA methylation levels $(16,37)$. Therefore, we studied the DNA methylation level of fasting mouse liver. In this study, no increase in DNA methylation occurred in fasting mouse liver. However, other methylation reactions appeared to increase, as indicated by the finding that AdoHcy, the demethylated product of the methyltransferase reaction, increased in the fasting mouse liver (Table 1). We searched the database about the relation between glycine $N$-methyltransferase, phosphatidylethanolamine $\mathrm{N}$-methyltransferase, or guanidinoacetate $\mathrm{N}$-methyltransferase expression and fasting. But no published reports exist on the relation between methyltransferase and fasting. At the present time, the reason why
AdoHcy increases in fasting mouse liver has not been established.

AdoHcy can negatively affect methylation potential in humans. Data from several recent studies suggest that hyperhomocysteinemia is accompanied by significant increases in plasma and intracellular AdoHcy (38). Hyperhomocysteinemia is a marker of vascular diseases (38). Thus, the inhibition of methylation reactions, in addition to the depression of the GSH level, is related to many diseases. Understanding the effects of diets on MAT expression and the methionine cycle is important for maintaining health. The mechanism of the regulation of MAT expression by fasting and other dietary changes is unclear. Further investigations are needed.

\section{REFERENCES}

1) Chou JY. 2000. Molecular genetics of hepatic methionine adenosyltransferase deficiency. Pharmacol Ther $\mathbf{8 5}$ $1-9$.

2) Cabrero C, Puerta J, Alemany S. 1987. Purification and comparison of two forms of $S$-adenosyl-L-methionine synthetase from rat liver. Eur J Biochem 170: 299-304.

3) Kotb M, Kredich NM. 1985. S-Adenosylmethionine synthetase from human lymphocytes. Purification and characterization. J Biol Chem 260: 3923-3930.

4) Mitsui K, Teraoka H, Tsukada K. 1988. Complete purification and immunochemical analysis of $S$-adenosylmethionine synthetase from bovine brain. J Biol Chem 263: 11211-11216.

5) Hiroki T, Horikawa S, Tsukada K. 1997. Structure of the rat methionine adenosyltransferase $2 \mathrm{~A}$ gene and its promoter. Eur J Biochem 250: 653-660.

6) LeGros L, Halim AB, Chamberlin ME, Geller A, Kotb M. 2001. Regulation of the human MAT2B gene encoding the regulatory $\beta$ subunit of methionine adenosyltransferase, MAT II. J Biol Chem 276: 24918-24924.

7) Lu SC, Alvarez L, Huang ZZ, Chen L, An W, Corrales FJ, Avila MA, Kanel G, Mato JM. 2001. Methionine adenosyltransferase 1A knockout mice are predisposed to liver injury and exhibit increased expression of genes involved in proliferation. Proc Natl Acad Sci USA 98: 5560-5565.

8) Cai J, Mao Z, Hwang JJ, Lu SC. 1998. Differential expression of methionine adenosyltransferase genes influences the rate of growth of human hepatocellular carcinoma cells. Cancer Res 58: 1444-1450.

9) Mato JM, Corrales FJ, Lu SC, Avila MA. 2002. S-Adenosylmethionine: a control switch that regulates liver function. FASEB J 16: 15-26.

10) Augoustides-Savvopoulou P, Luka Z, Karyda S, Stabler SP, Allen RH, Patsiaoura K, Wagner C, Mudd SH. 2003. Glycine N-methyltransferase deficiency: A new patient with a novel mutation. J Inherit Metab Dis 26: 745-759.

11) Vance DE, Walkey CJ, Cui Z. 1997. Phosphatidylethanolamine $\mathrm{N}$-methyltransferase from liver. Biochim Biophys Acta 1348: 142-150.

12) Finkelstein JD. 1990. Methionine metabolism in mammals. J Nutr Biochem 1: 228-237.

13) Auvinen M, Paasinen A, Anderson LC, Holtta E. 1992. Ornithine decarboxylase activity is critical for cell transformation. Nature 360: 355-358.

14) Mato JM, Alvalez L, Fernando J, Pajares MA. 1994. SAdenosylmethionine and the liver. In: The Liver. Biology 
and Pathobiology, 3rd ed (Arias IM, ed), p 461-470. Raven Press, New York.

15) James SJ, Melnyk S, Pogribna M, Pogribny IP, Caudill MA. 2002. Elevation in $S$-adenosylhomocysteine and DNA hypomethylation: potential epigenetic mechanism for homocysteine-related pathology. $J$ Nutr 132: 2361S-2366S.

16) Friso S, Choi SW. 2002. Gene-nutrient interactions and DNA methylation. J Nutr 132: 2382S-2387S.

17) Regina M, Korhonen VP, Smith TK, Alakuijala L, Eloranta TO. 1993. Methionine toxicity in the rat in relation to hepatic accumulation of $S$-adenosylmethionine: prevention by dietary stimulation of the hepatic transsulfuration pathway. Arch Biochem Biophys 300: 598607.

18) Doi T, Kawata T, Tadano N, Iijima T, Maekawa A. 1989. Effect of vitamin $\mathrm{B}_{12}$ deficiency on S-adenosylmethionine metabolism in rats. J Nutr Sci Vitaminol 35:1-9.

19) Villanueva JA, Halsted CH. 2004. Hepatic transmethylation reactions in micropigs with alcoholic liver disease. Hepatology 39: 1303-1310.

20) Radcliffe BC, Egan AR. 1978. The effect of diet and methionine loading on activity of enzymes in the transsulfuration pathway in sheep. Aust J Biol Sci 31: 105114.

21) Chomczynski P, Sacchi N. 1987. Single-step method of RNA isolation by acid guanidium thiocyanate-phenolchroloform extraction. Anal Biochem 162: 156-159.

22) Lehrach H, Diamond D, Wozney JM, Boodtker H. 1977. RNA molecular weight determinations by gel electrophoresis under denaturing conditions, a critical reexamination. Biochemistry 16: 4743-4751.

23) Sakata SF, Tamaoka K, Matsuda K, Kaneko M, Chou JY, Tamaki N. 1998. Effect of glucocorticoids on the mouse methionine adenosyltransferase A1 gene expression, which is regulated by two promoters. Biochim Biophys Acta 1442: 127-136.

24) Sakata SF, Shelly LL, Ruppert S, Schutz G, Chou JY. 1993. Cloning and expression of murine $S$-adenosylmethionine synthetase. J Biol Chem 268: 13978-13986.

25) Fujimoto S, Mizutani N, Mizota C, Tamaki N. 1986. The level of $\beta$-alanine aminotransferase activity in regenerating and differentiating rat liver. Biochim Biophys Acta 882: 106-112.

26) She QB, Nagao I, Hayakawa T, Tsuge H. 1994. A simple
HPLC method for the determination of $S$-adenosylmethionine and $S$-adenosylhomocysteine in rat tissue: the effect of vitamin $\mathrm{B}_{6}$ deficiency on these concentrations in rat liver. Biochem Biophys Res Commun 205: 17481754.

27) Baker MA, Cerniglia GJ, Zaman A. 1990. Microtiter plate assay for the measurement of glutathione and glutathione disulfide in large numbers of biological samples. Anal Biochem 190: 360-365.

28) Bidlingmeyer BA, Cohen SA, Tarvin TL. 1984. Rapid analysis of amino acids using pre-column derivatization. J Chromatogr 336: 93-104.

29) Preparation of genomic DNA from Mammalian tissues. In: Current Protocols in Molecular Biology (Ausubel FM et al., eds), p 2.2.1-2.2.3. John Wiley \& Sons, New York.

30) Balaghi M, Wagner C. 1993. DNA methylation in folate deficiency: use of CpG methylase. Biochim Biophys Res Commun 193: 1184-1190.

31) Christophe J, Winand J, Kutzner R, Hebbelinck M. 1971. Amino acid levels in plasma, liver, muscle, and kidney during and after exercise in fasted and fed rats. Am J Physiol 221: 453-457.

32) Mudd SH, Poole JR. 1975. Labile methyl balances for normal humans on various dietary regimens. Metabolism 24: 721-735.

33) Wu G, Fang YZ, Yang S, Lupton JR, Turner ND. 2004. Glutathione metabolism and its implication for health. J Nutr 134: 489-492.

34) $\mathrm{Ng} \mathrm{HH}$, Bird A. 1999. DNA methylation and chromatin modification. Curr Opin Genet Dev 9: 158-163.

35) Baylin SB, Herman JG, Graff JR, Vertino PM, Issa JP. 1998. Alteration in DNA methylation: a fundamental aspect of neoplasia. Adv Cancer Res 72: 141-196.

36) Chen RZ, Pettersson U, Beard C, Jackson-Grusby L, Jaenisch R. 1998. DNA hypomethylation leads to elevated mutation rates. Nature 395: 89-93.

37) Niculescu MD, Zeisel SH. 2002. Diet, methyl donors and DNA methylation: Interactions between dietary folate, methionine and choline. J Nutr 132: 2333S-2335S.

38) Castro R, Rivera CR, Struys EA, Jansen EE, Ravasco P, Camilo ME, Blom HJ, Jakobs C, Tavares de Almeida I. 2003. Increased homocysteine and $S$-adenosylhomocysteine concentrations and DNA hypomethylation in vascular disease. Clin Chem 49: 1292-1296. 